\title{
Effect of Black Pepper Extract (Piper nigrum L) towards Streptococcus Mutans Growth
}

\author{
(Pengatuh Ekstrak Lada Hitam (Piper nigrum L) terhadap Pertumbuhan Streptococcus Mutans \\ Rachmi Fanani Hakim, Fakhrurrazi, Fadli Alwi \\ Faculty of Dentistry Universitas Syiah Kuala \\ Jl. Tgk. Hasan Krueng Kalee, Kopelma Darussalam, \\ Kec. Syiah Kuala, Kota Banda Aceh, Aceh 23111 \\ rachmifananihakim@unsyiah.ac.id
}

\begin{abstract}
Streptococcus mutans is a Gram-positive facultative anaerobic bacteria which has become the main cause of dental caries. Black pepper (Piper nigrum L) is one of herbal plants that compose antibacterial compounds including alkaloids, flavonoids, tannins, and essential oils. This study aims to determine the effect of black pepper (Piper nigrum L.) extract to inhibit of Streptococcus mutansgrowth. Black pepper extracts ware made by using maceration method. The effect of black pepper extract ( Piper nigrum L. ) in inhibition of Streptococcus mutansgrowth by using the disc diffusion method on Mueller Hinton Agar media. The concentration of black pepper ( Piper nigrum L.) extracts used in this study were $6.25 \%, 12.5 \%, 25 \%, 50 \%, 75 \%$. The results of this study were analyzed by using the one-way ANOVA test showed that there was significant effect of black pepper extract on Streptococcus mutans growth with p-value ( $\mathrm{p}<0.05)$, and then the data was tested by Least Significant Difference (LSD). Conclusion of this study showed that there was an effect of black pepper ( Piper nigrum L.) extract in inhibition of Streptococcus mutans growth with concentrations $75 \%$ is the optimum concentration which value $16.8 \mathrm{~mm}$.
\end{abstract}

Key words: Streptococcus mutans, black pepper ( Piper nigrum L. ), disc diffusion method

\begin{abstract}
Abstrak
Streptococcus mutansmerupakan bakteri anaerob fakultatif Gram-positif yang menjadi penyebab utama karies gigi. Lada hitam (Piper nigrum L) adalah salah satu tanaman herbal mengandung senyawa antibakteri termasuk alkaloid, flavonoid, tanin, dan minyak esensial. Penelitian ini bertujuan untuk mengetahui pengaruh ekstrak lada hitam (Piper nigrum L.) dalam menghambat pertumbuhan Streptococcus mutans. Ekstrak lada hitam dibuat dengan menggunakan metode maserasi. Pengaruh ekstrak lada hitam (Piper nigrum L.) dalam menghambat pertumbuhan Streptococcus mutans dilakukan dengan menggunakan metode difusi cakram pada media Agar Mueller Hinton. Konsentrasi ekstrak lada hitam (Piper nigrum L.) yang digunakan dalam penelitian ini adalah 6.25\%, 12.5\%, 25\%, 50\%, 75\%. Hasil penelitian ini dianalisis dengan menggunakan uji ANOVA satu arah menunjukkan bahwa ada pengaruh signifikan ekstrak lada hitam terhadap pertumbuhan Streptococcus mutans dengan p-value( $<0.05)$, kemudian data diuji dengan Least Significant Difference (Least Significant Difference) LSD). Kesimpulan dari penelitian ini menunjukkan bahwa ada pengaruh ekstrak lada hitam (Piper nigrum L.) dalam menghambat pertumbuhan Streptococcus mutans, dengan konsentrasi optimum adalah $75 \%$ dengan nilai $16.8 \mathrm{~mm}$.
\end{abstract}

Kata kunci: Streptococcus mutans, lada hitam, metode difusi cakram

\section{INTRODUCTION}

Basic Health Research (RISKESDAS) in 2013 the national prevalence of dental and oral health problems in Indonesia the results showed one of the dental and oral health problems dental caries was $25.9 \% .^{1}$ Dental caries is a chronic disease lead to the process of demineralization in tissues hard teeth include progressive enamel, dentin, cementum. ${ }^{2}$ The are four factors that cause dental caries including the host, substrate, bacteria and time. The interaction of the four factors influence the formation of dental caries. $^{3}$

In the oral cavity, there is more than 700 species of bacteria can be found. ${ }^{4}$ Some bacteria associated with the occurrence of caries include Streptococcus mutans (S. mutans) and Lactobacillus sp. Many literatures mention that $S$. mutans is the main cariogenic microorganism that causes dental caries. ${ }^{4} S$. mutans ferment carbohydrates into produce organic acids 
and the process of tooth demineralization begins. $S$. mutans is acidophilic bacteria that can survive in low $\mathrm{pH}$, and can synthesize glucan in plaque formation. ${ }^{5}$

Currently there are many studies examining the various effects of traditional herbal plants in their use as antimicrobials, one of which is black pepper ( $P i$ per nigrum L.). Black pepper is also used to treat asthma, obesity, sinus, fever, stomach disease and diarrhea. ${ }^{6}$ The active compounds in black pepper extract include alkaloids, phenols, tannins, coumarin, saponins, flavonoids, glycosides and essential oils. ${ }^{7,8}$ Essential oil levels in black pepper are usually higher than white pepper, which is $2.0-2.6 \%$ essential oil and 6-13\% oleoresin. ${ }^{9}$ The results of Chandel's research (2014) show there are differences in active compounds among black pepper and white pepper. Black pepper extract in the same amount contains levels of piperine and essential oil respectively 4.9$7.7 \%$ and $1.0-1.8 \%$, while the white pepper extract has a content of 5.5-5.9 respectively $\%$ and 0.5 $0.9 \% .^{10}$

Based on the results of research conducted by Pundir and Pranay (2010) black pepper extract has antibacterial activity against Gram-positive Staphylococcus aureus bacteria with inhibitory $>10 \mathrm{~mm} .{ }^{11}$ Sidarta, et al (2013) reported that the essential oil, alkaloid and phenol content in White pepper extract can inhibit $S$. mutans at a concentration of $12.5 \% .^{12}$ The results of another study conducted by Rani, et al (2013) showed that the piperin content in black pepper showed antimicrobial activity with inhibition zones ranging from $8-18 \mathrm{~mm}$. The maximum zone of inhibition against gram-positive Staphylococcus aureus $(18 \mathrm{~mm})$ and the minimum against gramnegative bacteria Escherichia coli $(8 \mathrm{~mm})$. Piperin showed maximum antifungal activity against $F u s a-$ rium oxysporum $(14 \mathrm{~mm})$ and minimal effect on $A s$ pergillus niger $(38 \mathrm{~mm}){ }^{13}$

\section{MATERIALS AND METHOD}

This is an experimental laboratory design research with a post-test only control group design. The sample used in this study was the Streptococcus mutans bacteria obtained from the Microbiology Laboratory of the Faculty of Veterinary Medicine at Syiah Kuala University, while black pepper (Piper nigrum L.) originated from plantations in Lhoknga District, Aceh Besar.

Bacterial culture was carried out using the T stroke technique on the TYS20B media. Bacteria are inoculated using ose needles that have been sterilized in the first area with a zig-zag stroke. The ose needle is sterilized again, and the zig-zag stroke is continued in the second area, which is perpendicular to the first area. Petri dishes are rotated to get a perfect stroke, the same method is also used in the third area. To get an anaerobic atmosphere, a petri dish is put into a candle jar, then incubated in an incubator for $2 \times 24$ hours at $37^{\circ} \mathrm{C} .{ }^{14}$

The $S$. mutans colony confirmed by gram staining. Gram staining technique is done by taking the bacteria to be tested and then smeared on glass preparations. Moisten the smear with violet crystals gently and let stand for 1 minute. After that the lugol drops are prepared, wait for about one minute, and rinse using flowing distilled water. Decolorization uses 95\% ethyl alcohol or acetone. Tilt the slide slightly and apply alcohol dropwise for 5 to 10 seconds until the alcohol runs almost clear. Rinse again with aquades, drop safranin, and wait for about 1-2 minutes, then rinse with flowing distilled water, and allowed to dry. When the glass preparation is dry, drops of emersion oil and then $S$. mutans observe under microscope. S. mutans will appear purple. ${ }^{15}$

Black pepper (Piper nigrum L.) in the form of grains is ground using a blender to produce powder, then extracted using maceration method with ethanol 96\% solvent. All raw black pepper (Piper nigrum L.) powder is stored in a closed container with solvent and allowed to stand for a minimum period of three days with agitation frequency until the solvent material is dissolved. The mixture is then filtered, marc (wet solid material) pressed and filtered with whatman filter paper No. 1. The filtrate obtained was evaporated using a rotary evaporator solvent until the extract became thick or concentrated. ${ }^{12,16}$ Thick black pepper extract (Piper nigrum L.) concentration of $100 \%$ was diluted to obtain a concentration of $75 \%, 50 \%, 25 \%, 12.5 \%, 6.25 \%$ dilution was carried out with ethanol and homogenized using vortex.

The test was carried out using the disc diffusion method. The media used was Mueller Hinton Agar (MHA), using the spread method (spread) with the swab technique. The cotton swab is suspended by $S$. mutans pressed into the wall of the test tube until there are no more droplets. Then the cotton swab is applied thoroughly to the surface of the MHA media. The disc paper used was made of Whatman No. 1 paper with a diameter of $6 \mathrm{~mm}$. sixteen Disc paper was placed in black pepper extract with a treatment concentration of $75 \%, 50 \%, 25 \%, 12.5 \%$, and $6.25 \%$ so the disc it can absorb the extract perfectly.

The negative control groups used in this study were paper discs with distilled water, and paper discs with Chlorhexidine (CHX) $0.2 \%$ as positive controls with 3 repetitions each. The distance between the disc paper and the edge of the cup should be large enough so that the clear areas do not coincide. Disc 
paper is pressed using sterile tweezers on the surface of the MHA media. Incubate the media in an incubator at $37^{\circ} \mathrm{C}$ for 24 hours in an anaerobic atmosphere. ${ }^{16}$

After incubation, the inhibition of black pepper extract (Piper nigrum L.) and the control group can be seen in the clear zone formed around the disc paper.This clear area is an area of growth inhibition of bacteria including the diameter of the disc. Furthermore, the inhibition zone diameter is calculated using calipers to obtain data to be used in the analysis. The measurement results obtained are interpreted based on the Ahn classification. ${ }^{17}$

Research results that have been collected, then tabulated data. The data obtained in the study were analyzed with the Anova one-way test, followed by the LSD test using the Statistical Package for the Social Scienses (SPSS) 19application to determine the effect of giving various concentrations of black pepper extract (Piper nigrum $L$ ) to the growth of $S$. mutans. $^{18}$

\section{RESULT}

Black pepper (Piper nigrum L.) used in this study was collected from the Lhoknga Aceh Besar estate as much as 930 grams. Black pepper (Piper nigrum $L$.) extraction by maceration method, which is 700 grams of dried black pepper seeds, blended into powder, soaked using $96 \%$ ethanol as much as two liters and filtered using filter paper. The extract was then evaporated using a rotary evaporator so that 50 grams of concentrated black pepper (Piper nigrum $L$.) extract was obtained.

Streptococcus mutans was cultured on the Mueller Hinton agar medium by the $\mathrm{T}$ streaking technique after incubation for $2 \times 24$ hours at 37 temperature under anaerobic conditions (Figure 1.a). The results of the culture were observed in a light microscope with magnification 100 times, visible colony of purple bacteria with a coccus and chain shape (Figure 1.b).

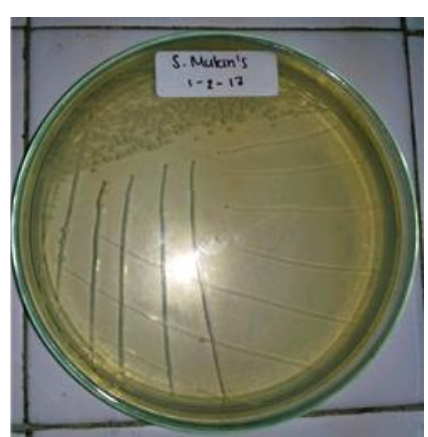

Figure 1a . S. mutans colony on the MHA

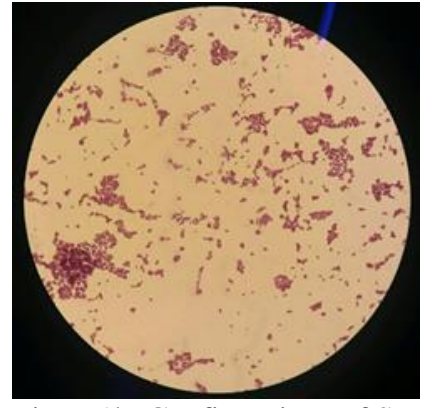

Figure1b. Confirmations of S.mutans

The results of the test of the effect of black pepper extract on the growth of $S$. mutans were carried out by measuring the diameter of the inhibitory zone or clear zone formed around the disc at various concentrations as well as negative and positive controls in this study carried out with three repetitions, the measurement results are in table 1.

Table 1. Test Results of Effect of Black Pepper Extract (Piper nigrum L.) on S. mutans Growth

\begin{tabular}{|c|c|c|c|c|}
\hline $\begin{array}{c}\text { Concentratio } \\
\mathrm{n}\end{array}$ & & $\begin{array}{c}\text { Inhibition } \\
\text { Zone } \\
(\mathrm{mm})\end{array}$ & & $\begin{array}{l}\text { Inhibition Zone } \\
\text { Average (mm) }\end{array}$ \\
\hline & $\mathrm{R} 1$ & $\mathrm{R} 2$ & R3 & \\
\hline $\begin{array}{l}\text { Negative } \\
\text { Control } \\
\text { (aquades) }\end{array}$ & 0 & 0 & 0 & 0 \\
\hline $\begin{array}{l}6,25 \% \\
\text { concentration }\end{array}$ & 12.2 & 13 & 12 & 12.4 \\
\hline $\begin{array}{l}12,5 \% \text { concen } \\
\text { tration }\end{array}$ & 13.5 & 13.6 & 14 & 13.7 \\
\hline $\begin{array}{l}25 \% \text { concentr } \\
\text { ation }\end{array}$ & 15 & 15.2 & 14.5 & 14.9 \\
\hline $\begin{array}{l}50 \% \text { concentr } \\
\text { ation }\end{array}$ & 16 & 16.5 & 15 & 15.83 \\
\hline $\begin{array}{l}75 \% \text { concentr } \\
\text { ation }\end{array}$ & 16.8 & 17 & 16 & 16.6 \\
\hline $\begin{array}{l}\text { Positive } \\
\text { Control } \\
(\mathrm{CHX})\end{array}$ & 17 & 17.1 & 16.5 & 16.87 \\
\hline
\end{tabular}

Statistical test results using one-way Anova with $\mathrm{p}$ value $<0.05$, showed that black pepper extract (Piper nigrum $L$.) had a significant influence on the growth of $S$. mutans. The results of further tests using the Least Significant Difference (LSD) showed that there were significant differences between all groups analyzed, except treatments that did not have a significant effect were concentrations of $50 \%$ and $75 \%$ with $\mathrm{p}=0.58$ and $75 \%$ concentration and positive control with values $p=0.484$, less than 0.05 or mean difference is smaller than the LSD value, as seen in table 2. 
Table 2. Statistical test results using Least Significant Difference (LSD)

\begin{tabular}{|c|c|c|c|c|c|c|c|}
\hline & $\mathrm{K}(-)$ & $\begin{array}{l}\text { K- } \\
6,25 \\
\% \\
\end{array}$ & $\begin{array}{l}\text { K- } \\
12,5 \\
\% \\
\end{array}$ & $\begin{array}{l}\mathrm{K}- \\
25 \%\end{array}$ & $\begin{array}{l}\mathrm{K}- \\
50 \%\end{array}$ & $\begin{array}{l}\text { K- } \\
75 \%\end{array}$ & $\begin{array}{l}\mathrm{K}(+ \\
)\end{array}$ \\
\hline $\mathrm{K}(-)$ & - & $\begin{array}{c}.000 \\
*\end{array}$ & $\begin{array}{c}.000 \\
*\end{array}$ & $\begin{array}{c}.000 \\
*\end{array}$ & $\begin{array}{c}.000 \\
*\end{array}$ & $\begin{array}{c}.000 \\
*\end{array}$ & $\begin{array}{l}.00 \\
0^{*}\end{array}$ \\
\hline $\begin{array}{l}\mathrm{K}- \\
6,25 \\
\%\end{array}$ & $\begin{array}{c}.000 \\
*\end{array}$ & - & $\begin{array}{c}.004 \\
*\end{array}$ & $\begin{array}{c}.000 \\
*\end{array}$ & $\begin{array}{c}.000 \\
*\end{array}$ & $\begin{array}{c}.000 \\
*\end{array}$ & $\begin{array}{l}.00 \\
0^{*}\end{array}$ \\
\hline $\begin{array}{l}\text { K- } \\
12,5 \\
\%\end{array}$ & $\begin{array}{c}.000 \\
*\end{array}$ & $\begin{array}{c}.004 \\
*\end{array}$ & - & $\begin{array}{c}.006 \\
*\end{array}$ & $\begin{array}{c}.000 \\
*\end{array}$ & $\begin{array}{c}.000 \\
*\end{array}$ & $\begin{array}{l}.00 \\
0^{*}\end{array}$ \\
\hline $\begin{array}{l}\mathrm{K}- \\
25 \%\end{array}$ & $\begin{array}{c}.000 \\
*\end{array}$ & $\begin{array}{c}.000 \\
*\end{array}$ & $\begin{array}{c}.006 \\
*\end{array}$ & - & $\begin{array}{c}.025 \\
*\end{array}$ & $\begin{array}{c}.000 \\
*\end{array}$ & $\begin{array}{l}.00 \\
0 *\end{array}$ \\
\hline $\begin{array}{l}\mathrm{K}- \\
50 \% \\
\end{array}$ & $\begin{array}{c}.000 \\
* \\
\end{array}$ & $\begin{array}{c}.000 \\
* \\
\end{array}$ & $\begin{array}{c}.000 \\
* \\
\end{array}$ & $\begin{array}{c}.025 \\
* \\
\end{array}$ & - & .058 & $\begin{array}{l}.01 \\
5^{*} \\
\end{array}$ \\
\hline $\begin{array}{l}\text { K- } \\
75 \%\end{array}$ & $\begin{array}{c}.000 \\
*\end{array}$ & $\begin{array}{c}.000 \\
*\end{array}$ & $\begin{array}{c}.000 \\
*\end{array}$ & $\begin{array}{c}.000 \\
*\end{array}$ & .058 & - & $\begin{array}{c}.48 \\
4\end{array}$ \\
\hline $\mathrm{K}(+)$ & $\begin{array}{c}.000 \\
*\end{array}$ & $\begin{array}{c}.000 \\
*\end{array}$ & $\begin{array}{c}.000 \\
*\end{array}$ & $\begin{array}{c}.000 \\
*\end{array}$ & $\begin{array}{c}.015 \\
*\end{array}$ & .484 & - \\
\hline
\end{tabular}

\section{DISCUSSION}

Based on Table 1. the classification of inhibitory ability according to Ahn, shows that black pepper extract (Piper nigrum $L$.) can inhibit the growth of $S$. mutans at each concentration of the test with a weak to moderate inhibitory ability. Inhibition zone diameters of $6.25 \%, 12.5 \%, 25 \%$ have an average inhibition diameter of $12.4 \mathrm{~mm}, 13.7 \mathrm{~mm}$ and $14.9 \mathrm{~mm}$ including the weak inhibitory capability. While the concentrations of $50 \%$ and $75 \%$ have a diameter of inhibition of $15.83 \mathrm{~mm}$ and $16.6 \mathrm{~mm}$ included in the classification of moderate inhibition.

The formation of inhibitory zones around the disc shows the presence of antibacterial compounds in black pepper extracts such as alkaloids, phenols, tannins, coumarin, saponins, glycosides and astiri oil. ${ }^{7,8}$ Test results show an enhancement in the percentage of extract concentration resulting in an increase in the diameter of bacterial inhibition zones. this is due to the higher concentration of more active substances contained in it, so that it can affect the inhibitory zone formed. This assumption is in line with the research of Sidarta et al. (2013) using the diffusion test of white pepper extract with a concentration of $6.25 \%$ to $100 \%$ having an inhibitory diameter of 10 $16 \mathrm{~mm} .{ }^{12}$ Another study on the relationship line enhancement and inhibition zone extract is also found in the study Andayani et al.(2012). ${ }^{14}$

The formation of inhibitory zones around the disc shows the presence of antibacterial compounds in black pepper extracts such as alkaloids, phenols, tan- nins, coumarin, saponins, glycosides, and astiri oil. ${ }^{7,8}$ Essential oils can damage the cell walls of bacteria, causing bacterial lysis. ${ }^{12}$ Piperin, piperitin, piperidin, are alkaloid groups that have properties that can eliminate DNA and can also inhibit bacteria growth. Other ingredients found in black pepper extract are flavonoids and tannins. Flavonoids play a role in denaturazing proteins and damaging the bacterial cell membrane, bind hydrogen atoms and eliminate bacteria by inhibiting the synthesis of nucleic acids. Tannins are a group of polyphenols that can bind bacterial proteins, if there is adhesion there can be damage to receptors on the surface of bacterial cells. $^{12}$

There are two controls in this study, Clorhexidine (CHX) $0.2 \%$ as a positive control and distilled water as a negative control. The results of CHX $0.2 \%$ inhibition test against $S$. mutans showed an average inhibition zone of $16.87 \mathrm{~mm}$. These results are also in line with the CHX $0.2 \%$ test of $S$. mutans conducted by Sinaredi, et al (2014) showing that the formation of inhibition zones with a diameter of $16.08 \mathrm{~mm} .{ }^{19}$ The difference in the size of the inhibition zone of $75 \%$ black pepper extract with positive control was $0.27 \mathrm{~mm}$ higher positive control, however both treatments have moderate bacterial inhibitory ability. Based on measurements and statistical tests it is known that there is no significant difference between the two treatments above.

The use of CHX $0.2 \%$ is usually used as a mouthwash which serves to diminish the formation and detain plaque growth. CHX is a bisbiguanid antiseptic compound that has bacteriostatic and bacteriosid properties against a variety of bacteria including bacteria in plaque, one of which is $S$. mutans. CHX molecules have a positive charge (cation) and most bacteria have a negative charge (anion), this potency effect became strong attachment of CHX to the bacterial cell membrane. CHX may cause changes in the permeability of bacterial cell membranes, causing the release of cell cytoplasm and low molecular weight cell components from inside the cell through the membrane bring out bacterial death. ${ }^{19}$

The presence of antibacterial compounds of black pepper extract as well as alkaloids, flavonoids, tannins, essential oils and CHX affect the diameter of the growth inhibition zone of $S$. mutansin this study. In contrast to the two treatments above negative control in this study that distilled water does not have the ability to inhibit bacteria indicated by the absence of a clear zone around the disc. ${ }^{14}$

Statistical test results using one-way Anova with $\mathrm{p}$ value $<0.05$, showed that black pepper extract (Piper nigrum $L$.) had a significant influence on the growth of $S$. mutans. The results of further tests using Least 
Significant Difference (LSD) showed that there were significant differences between all groups analyzed, except treatments that did not have a significant ef-fect were concentrations of $50 \%$ and $75 \%$ with $\mathrm{p}$ va-lues $=0.58$ and $75 \%$ concentrations and positive controls with values $\mathrm{p}=0.484$, less than 0.05 or mean difference is smaller than the LSD value.

Limitationsof this study are only knowing the ability of black pepperextracts to inhibit bacteria, it is also necessary to know the ability bactericidal of this extracts. This study only uses extract concentrations up to $75 \%$, research needs to be done at a $100 \%$ con-

\section{REFERENCES}

1. Kementrian Kesehatan RI. Riset Kesehatan Dasar. Jakarta: Badan Penelitian dan Pengembangan Kesehatan RI, 2013: 110.

2. Karpinski TM, Szkaradkiewicz AK. Microbiology of dental caries. J Biol. Earth Sci. 2013; 3(1): 214.

3. Ozdemir D. Dental caries: The most common disease worldwide and prevent strategies. Int. J Biol 2013; 5(4): 55-61.

4. Forssten SD, Bjorklund M, Ouwehand AC. Streptococcus mutans, caries, and simulation model. Nutrients 2010; 2: 290-8.

5. Hakim RF. Peran glukosiltransferase streptococcus mutans dalam menginduksi terbentuknya karies. Cakradonya Dent J 2009; 2(1): 21-2.

6. Alkryl HF, Abdurrahman ZF. Evaluation of the antibacterial efficacy and the phytochemical analysis of some plant extracts against human pathogenic bacteria. JPCS 2013; 7: 1-2.

7. Nahak G, Sahu RK. Phytochemical Evaluation and Antioxidant Activity of Piper cubeba and Piper nigrum. JAPS 2011; 1(8): 153-7.

8. Trivedi MN, Khemani UD, Vachhani. Pharmacognostic, phytochemical analysis and antimicrobial activity of two piper species. IJCP 2011; 7(5): 1-4.

9. Parthasarathy VA, Chempakam B, Zachariah TJ. Chemistry of spices. Pondicherry: Cabi, 2008: 225 .

10. Chandel VS, Khan MS, R M, Singh SP. Comparative dielectric behaviour of black pepper and white pepper. EJAET 2014; 1(1): 43-7.

11. Pundir RK, Pranay J. Comparative studies on the antimicrobial activity of black pepper (Piper nigrum) and tumeric (Curcuma longa) extracts. Int. J. Appl. Biol. Pharm. 2010; 1(2): 491-500.

12. Sidarta YO, Prasetyaningrum N, Fitriani D, et.al. White pepper extract (Piper nigrum L.) as antibacterial agent for Streptococcus mutans in vitro. IOSR J. Dent. Med. Sci. 2013; 4(6): 25-9. centration whichthere is more active substances in the extract.

This study conclude that Black pepper extract ( $P i$ per nigrum L.) can inhibit the growth of Streptococcus mutans. Black pepper extract at a concentration of $6.25 \%, 12.5 \%$ and $25 \%$ can inhibit $S$. mutans with inhibitory ability of the weak category, while $50 \%$ and $75 \%$ can inhibit the moderate category. The optimum concentration of black pepper (Piper nigrum L.) extract in inhibit of Streptococcus mutans growth is $75 \%$ concentrations.

13. Rani SK, Saxena N, Udaysree. Antimicrobial Activity of black pepper (Piper nigrum L.). GJP 2013; 7(1): 87-90.

14. Andayani R, Gani B, Hindayani W. Uji hambat ekstrak etaol daun saga (abrusorecation linn) terhadap pertumbuhan Streptococcus mutans. Cakradonya Dent J 2012; 4(1): 427-31.

15. Soraya C, Chismirina S. Aktifitas antibakteri propolis terhadap pertumbuhan Streptococcus mutans dan Enterococcus facealis. Cakradonya Dent J 2012; 3(2): 356-65.

16. Hakim RF, Fakhrurazi, Masnaini. Perbandingan daya hambat ekstrak daun dan buah jambu biji (psidium guajava) terhadap aktivitas bakteri bakteri Enterococcus faecalis. Medika Kartika: J Kedokteran dan kesehatan 2020; 3(2): 126-38.

17. Alfath CR, Yulina V, Sunnati. Antibacterial effect of Granati fructus cortex extract on Streptococcus mutans in vitro. J Dent Indonesia 2013; 1: 5-8.

18. Dahlan SM. Statistik untuk kedokteran dan kesehatan. Jakarta: Salemba Medika; 2011: 88-95.

19. Sinaredi BR, Pradopo S, Wibowo TB. Daya antibakteri obat kumur chlorhexidine, povidone iodine, flouride suplementasi zinc terhadap, Streptococcus mutans dan Porphyromonas gingivalis. Dent J 2014; 47 (4): 211-4. 